\title{
Concentrated Dosage Form
}

National Cancer Institute

\section{Source}

National Cancer Institute. Concentrated Dosage Form. NCI Thesaurus. Code C60891.

A solution or suspension composed of active and/or inert ing redient(s) with increased strength in a reduced volume, which is usually diluted prior to administration. 